\title{
ФІЛОСОФІЯ ОСВІТИ
}

УДК 37.01:316.323.6(477)

DOI 10.35423/2078-8142.2020.2.2.12

M. O. Kim, аспірант Національного педагогічного університету імені М. П. Драгоманова, м. Київ, Украӥна e-mail:kit-mi@ukr.net ORCID: https://orcid.org/0000-0002-3971-7063

\section{ФІЛОСОФІЯ ОСВІТИ РИНКОВО ОРІЕНТОВАНОГО СУСПІЛЬСТВА: ДОСВІД ДЛЯ УКРАЇНИ}

У статті підкреслюється, що школа в сучасному світі орієнтується на повноцінну підготовку молодої людини до успішного життя. Це вимагає застосування принщипово нової філософії освіти, яка відповідала б потребам ринково орієнтованого, конкурентного соиіуму. Важливо вивчати західні моделі організації освітніх систем для використання їх досвіду в успішній трансформації української освітньої галузі. Відзначається, щзо філософія освіти ринково орієнтованого суспільства спрямована на інноваційні зміни у системі освіти, на оптимізацію мережі навчальних закладів, на підняття якості навчально-виховного процесу тощо. Досліджуючи досвід західних крайн, Україна має вибудувати власну освітню модель, яка може базуватися на принџипах децентралізації, інновачійності, соціально-економічних стимулів до науково-педагогічної діяльності, демократичності у побудові відносин між суб'єктами освітнього поля.

Ключові слова: філософія освіти, освітня система, ринкове суспільство, децентралізація.

На сьогоднішній день філософія освіти ринково орієнтованого суспільства $є$ домінуючою парадигмою трансформації освітнього простору України, яка намагається орієнтуватися на кращі захі-

(C) Кіт M. O., 2020 
дні зразки. Філософія освіти ринково орієнтованого суспільства, яка реалізується у країнах Заходу, базується у практичній площині на системі стимулів та преференцій для викладачів, науковців та навчальних закладів, які демонструють найкращі результати за прозорими й чітко визначеними критеріями. У контексті нашого дослідження важливо підкреслити, що у багатьох західних країнах система надання освітніх послуг $є$ децентралізованою. В умовах ринкової економіки важливим є не лише державне регулювання розвитком освітньої галузі, а й врахування потреб окремих територій у спеціалістах певного профілю.

Українська освітня система все ще перебуває на етапі переходу від застарілих авторитарних форм навчання до нових стандартів та методів. Особливу роль у цьому відіграли в останні роки процеси децентралізації, які докорінним чином вплинули на розподіл повноважень і ресурсів між центральною державною владою, регіональними осередками і місцевими громадами. Це не могло не заторкнути й освітню сферу, адже сьогодні вона $є$ однією 3 фундаментів у розвитку громадянського соціуму. Навколо шкіл, коледжів, спеціалізованих освітніх закладів, університетів формується життя громад, великих колективів, цілих міст і регіонів.

Досвід західних систем освіти, який можна застосовувати для успішної реформи вітчизняної освітянської сфери, аналізується українськими дослідниками у найрізноманітніших аспектах. 3 точки зору філософії освіти в останнє десятиліття особливий внесок у такі дослідження зробили В. Андрущенко, В. Береза, В. Бех, О. Висоцька, В. Горлинський, Т. Десятов, В. Кремень, В. Огнев'юк, Л. Маргуліна, В. Маслов, Я. Мельник, М. Михальченко, В. Молодиченко, Т. Сігіда, О. Співаковський, О. Якимчук та ін. Новизна нашого дослідження полягає в тому, що філософсько-освітня проблематика розглядається на тлі тенденцій децентралізації, що стали в останнє десятиліття потужним джерелом українського державотворення.

Метою дослідження є формулювання ключових принципів та напрямів філософії освіти ринково орієнтованого суспільства. Вивчення та аналіз досягнень західних моделей організації систем освіти, які могли б бути використаними і в сучасний державотвор- 
чий період в Україні, де особливо гостро постає проблематика реформування національної освітньої галузі.

Сучасна освіта стає дедалі більш прагматичною під впливом розвитку ринкових відносин - необхідності підготовки фахівця до виконання конкретних професійних функцій, забезпечення універсальності його знань та навичок, професійної мобільності тощо. Вочевидь, філософія освіти ринково орієнтованого суспільства має низку відмінностей від класичної парадигми освіти.

На думку вітчизняних фахівців, стан класичної парадигми дедалі більше визначається як кризовий з наступних причин. Поперше, тому, що вона $є$, як вважають представники Римського клубу, «підтримуючою освітою», переважно зорієнтованою на репродуктивне знання. Процес навчання зводився до здобування знань, умінь, навичок шляхом поступового накопичення матеріалу, до шаблонного його застосування у різних видах діяльності. Подруге, iï сцієнтистський, раціонально-знаннєвий, технократичний характер суперечить потребам гуманізації, «олюднення» знання в сучасному суспільстві. Ситуація в освіті ускладнюється так званим інформаційним бумом і спричиненою ним інформаційною кризою. По-третє, поряд і з раціоналізмом як однієї з провідних засад класичної парадигми освіти «значних втрат» зазнала ідея про універсальність європейських цінностей та способів життя. Теперішня геокультурна та геополітична картина світу стає більш схожою на плюралістичний образ дискурсу різних цивілізацій із ціннісно рівнозначними історичними надбаннями, ніж на втілення ідеї загального руху всіх країн до єдиної суспільної довершеності. Почетверте, пошук нових моделей освіти зумовлений необхідністю розробки механізмів адаптації людини до мінливого світу, а також зростанням розбіжності між порівняно сталими пізнавальними можливостями і світом, що дедалі більше ускладнюється [1, с. 39].

Можна стверджувати, що ринкові відносини у сталих демократіях $є$ вагомим чинником перебудови освітніх систем під потреби суспільства. Філософія ринкових відносин проникла в усі сфери суспільства та стала каталізатором для трансформації систем освіти у західних країнах, появи ринку освітніх послуг, освітнього маркетингу та освітнього менеджменту тощо. Досвід цих країн варто 
вивчати і в Україні, щоб напрацювати власну ефективну освітню модель.

Зокрема, у західних країнах освітній маркетинг розвивається передусім як управлінська парадигма діяльності в умовах становлення ринку освітніх послуг. Загальним концептуальним та соціальним тлом цього процесу є глибинні сутнісні зміни у самій освітній сфері, пов'язані з взаємопроникненням соціоцентричних та ринкових процесів управління в контексті формування інформаційного суспільства. Тому найбільше значення має маркетинг як інтегративна функція освітнього управління, через яку реалізується його соціокультурна детермінація. Сучасне управління освітою не лише виявляє дедалі більшу залежність від свого соціальнокультурного контексту, від соціально-культурного середовища, а й само набуває рис технології соціально-культурного нововведення. Управління освітою дедалі більше постає як репрезентація соціальних цінностей та певної культури $[2$, с. 7].

Сучасна філософія освіти, зорієнтована на ринкові відносини, потребує не комерціалізації освітнього простору (як іноді це сприймають в Україні), а оптимізації кількісно-якісних параметрів взаємодії всіх суб'єктів у межах наявних ресурсів. Досвід найрозвиненіших західних країн засвідчує, що «суспільство знань» та ринкові відносини потребують соціоцентричного спрямування освітнього маркетингу.

На переконання С. Ситниченка, основними напрямами реалізації освітнього маркетингу як управлінської інноваційної парадигми у контексті соціоцентричної орієнтації є такі: по-перше, це набуття освітнім маркетингом властивостей одного із системних механізмів регулювання освітніх процесів. Становлення елементів «суспільства освіти» скрізь супроводжується розвитком національних систем освітнього маркетингу, в межах яких узгоджуються інтереси суспільства, людини та освітнього ринку; по-друге, це формування соціоцентричного цілепокладання у сфері освітнього маркетингу. Незважаючи на те, що у більшості розвинених країн освітня сфера $є$ дуже комерціоналізованою, по суті одним 3 найпотужніших секторів бізнесу, домінування соціального ефекту над прибутковістю скрізь $є$ основною характеристикою як системи освіти загалом, так і діяльності окремих виробників освітніх пос- 
луг. Досягається це саме за рахунок формування соціоцентричних маркетингових систем в освіті, які забезпечують максимальний комерційний успіх лише в умовах орієнтації на довгострокові інтереси споживачів освітніх послуг та суспільства; по-третє, це трансляція маркетингом в освітню діяльність нових ціннісносвітоглядних орієнтирів, пов'язаних зі становленням «суспільства освіти». Загальною характеристикою цієї нової системи цінностей $\epsilon$ утвердження людини та потреб ії саморозвитку в якості абсолютного пріоритету всіх сфер соціального життя [3, с. 52].

Філософія освіти ринково орієнтованого суспільства, яка реалізується у країнах Заходу, грунтується у практичній площині на системі стимулів та преференцій для викладачів, науковців та навчальних закладів, які демонструють найкращі результати за прозорими й чітко визначеними критеріями.

Наприклад, у Бельгії (французька та німецька частина), якщо вчителі початкової або неповної середньої школи здобувають ступінь магістра, їхній оклад підвищується до рівня окладу вчителів старших класів середньої школи, для яких кваліфікація магістра $є$ вимогою для працевлаштування. Більш ніж у третині країн СС вчителі можуть отримувати додаткові надбавки за якість їхньої роботи після проведення атестації або на основі якісної успішності своїх учнів. У Чеській Республіці ця надбавка становить 3,9 \%, а в Латвії - від 7\% до 12\% від основного окладу. У Польщі директор школи за погодженням 3 місцевими органами управління освіти надає «мотиваційні стимули» за належне викладання, впровадження інновацій, відданість викладацькій діяльності і за виняткові досягнення під час виконання завдань і професійних обов'язків. У Сполученому Королівстві (Англії, Уельсі та Північній Ірландії) кожна школа проводить атестацію, за результатами якої учителі рухаються шкалою окладів. У випадку високих результатів вони можуть піднятися на 2 рівні. У Словенії, наприклад, виплачуються надбавки за викладання у двомовних класах. У Швеції наявність у класі учнів, що мають труднощі у навчанні, або учнів з особливими потребами може бути прийнятою до уваги під час індивідуальних переговорах щодо зарплати. У деяких країнах СС участь у позакласних заходах оплачується як понаднормова робота, а в інших 
за нею виплачують окрему надбавку. Так, у Словенії навчальні класи на відкритому повітрі (šola v naravi) винагороджуються до 20 \% від основної заробітної плати за 6 годин на день у початковій і неповній середній школі. Крім того, за проведення семінарів, спортивних та інших позакласних заходів (interesne dejavnosti) виплачується 11,94 євро на годину. Також, учителі в усіх європейських країнах, за винятком Кіпру, Латвії, Мальти, Румунії, Великобританії (Шотландія), отримують додаткові надбавки за понаднормову роботу, тобто робочий час, який перевищує кількість робочих годин, встановлених у трудовому договорі. У більшості випадків погодинна ставка за понаднормову роботу визначається центральним органом управління як певний відсоток від базового окладу. У Болгарії, Греції, Іспанії встановлюється конкретна фіксована сума. Майже в половині країн виплачують надбавки, пов'язані з географічним розташуванням школи. Вони є мотиваційними стимулами, які заохочують вчителів працювати у віддалених, сільських або соціально неблагополучних регіонах, і визначаються на центральному рівні управління. Також учителі можуть отримувати надбавки за роботу у регіонах з вищим за середній рівень життя, наприклад, у столиці. Критерії таких надбавок значно відрізняться в різних країнах. Вони можуть мати географічний характер (віддалені та ізольовані райони), що має місце в Данії, Іспанії, на Кіпрі, в Польщі, Румунії, Фінляндії та Великобританії (Шотландія). Водночас, вони можуть мати економічний (високий рівень життя), як у Франції та Великобританії (Англія), або соціальний характер (райони зі значним соціальним відчуженням, 3 високим ризиком чи 3 великою часткою учнів, що представляють етнічні чи мовні меншини) як в Іспанії, Франції та Італії [4, с. 111-112].

У багатьох західних країнах система надання освітніх послуг $\epsilon$ децентралізованою. В умовах ринкової економіки важливим $\epsilon$ не лише державне планування розвитку освітньої галузі, а й урахування потреб окремих територій у спеціалістах певного профілю. У зв'язку з цим освіта у демократичних країнах фінансується з різних джерел.

Зокрема, переважна більшість громад Польщі витрачає на освіту значно більше коштів, ніж отримує у вигляді освітньої субвенції з державного бюджету. Наприклад, у Варшаві до отриманої 
освітньої субвенції з міського бюджету докладається ще стільки ж. Найважливішою причиною $є$ «розбудова» освітньої системи, тобто того, що безпосередньо пов'язано з навчальним процесом, з психологічно-педагогічною, логопедичною, виховною опікою, тобто допомогою в розвитку дитини. Із поточних коштів утримання освітньої мережі місто видає кошти також і на ремонти цих об'єктів. Якщо йдеться про фінансування освітніх завдань, що реалізуються повітами (районами), то тут освітня субвенція покриває близько 95\% видатків, що призначені на реалізацію цієї мети. Залишок видатків покривається за рахунок інших доходів району - цільових дотацій та власних доходів. Як і у випадку з дошкільними закладами, існує можливість отримання європейських коштів для шкіл як громадами, так і районами, до того ж як на фінансування інвестиційних заходів, так і на «м'які» заходи. «М'які» заходи переважно стосуються організації додаткових (позалекційних) занять, а також професійного навчання. Підкреслимо, що отримання такого грантового фінансування є непростим процесом, як через велику кількість формальних вимог і складну процедуру підготовки заявки, так і через значну конкуренцію між ОМС [5, с. 64].

Корисним для України також $є$ досвід організації опорних шкіл (ОШ) за кордоном, мережа яких поступово розбудовується і в нашій країні. Створюючи ОШ, при наявності належної інфраструктури у державі, можна не лише заощадити матеріальні ресурси, а й підняти рівень надання освітніх послуг.

Досвід зарубіжних країн, де успішно працює інституція опорних шкіл, передбачає: 1) збір актуальних статистичних даних для аналізу і здійснення прогнозів щодо оптимізації неефективної мережі навчальних закладів. Актуальні статистичні дані є вагомим джерелом інформації для органів управління освітою для прийняття виважених управлінських рішень. На основі надійних статистичних даних формується політика на рівні держави щодо засадничих принципів створення і функціонування опорних шкіл, організації навчально-виховного процесу, інклюзивного навчання як важливої складової реалізації принципу рівного доступу до якісної освіти тощо. Додатковим інструментом для панорамного бачення проблем і викликів щодо функціонування опорних шкіл є моніто- 
ринг їх діяльності. Саме цьому напряму приділяється особлива увага в європейському освітньому просторі, країнах Північної та Південної Америки; 2) застосування стратегічного планування наповнюваності шкіл і класів з урахування ситуативного (місцевого) фактору. Це досягається завдяки аналізу, який базується на достовірних, актуальних статистичних даних. Наявні статистичні дані дають можливість доводити та оприлюднювати результати управлінських рішень щодо опорних шкіл на рівні держави до широких верств, залучати до співпраці місцеві громади, батьків, учителів. Важливим аспектом діяльності ОШ $є$ фінансування. Своєю чергою, розподіл коштів має грунтуватись на аналізі достовірних, актуальних та повних даних, що зібрані про діяльність ОШ. Вивчаючи інституційний розвиток опорних шкіл, міжнародні освітні експерти узагальнили типові помилки, які допускаються на перших етапах організації ОШ: а) відсутність стратегічного бачення, моделі розвитку, мети функціонування ОШ на рівні держави; б) відсутність надійних статистичних даних для здійснення аналізу прогнозів щодо оптимізації навчальних закладів; в) відсутність інституту відкритих даних щодо функціонування ОШ [6, с. 65-66].

Водночас, створення опорних шкіл в Україні потребує комплексного вирішення низки проблем, а саме: розбудови оптимальної мережі таких навчальних закладів; побудови доріг, які з'єднали б найвіддаленіші населенні пункти 3 місцем розташування ОШ; розв'язання соціально-економічних проблем учителів та школярів; забезпечення належної навчально-методичної та матеріальнотехнічної бази опорних шкіл тощо.

Загалом філософія освіти ринково орієнтованого суспільства у іiі західному варіанті спрямована на постійне осучаснення знань, підвищення рівня освітніх послуг, забезпечення доступності громадян до навчальних закладів різного рівня, створення умов для навчання протягом життя, підтримання практичної спрямованості освіти та ін.

Як зауважує О. Локшина аналізуючи європейську систему освіти, підвищення якісного рівня освітніх послуг та, відповідно, отриманих учнями знань стало панівною ідеєю другого періоду підвищення якості та результативності, який з початком XXI ст. трансформується у третій - період посилення ефективності та 
справедливості, що було спричинено новими завданнями, які $\mathrm{CC}$ проголосив на межі століть в умовах загострення існуючих та появи нових викликів. Наймасштабнішим, загальноцивілізаційним викликом у XXI ст. є перехід людства від індустріального до постіндустріального суспільства, в економіці якого під впливом науково-технічної революції та зростання доходів населення акцент зміщується від виробництва товарів до виробництва послуг, а інформація та знання перетворюються на домінуючий виробничий peсурс. Економічний успіх країн починає визначатися вже не лише рівнем промислового чи сільськогосподарського виробництва, а й інформаційними потоками та використанням нових знань. У цих умовах найбільш цінними якостями працівників, поряд з високим професіоналізмом, стають уміння ефективно управляти інформацією, самостійно приймати рішення та постійно удосконалювати знання, що потребує зміни усталеного гасла освіти «навчати усіх усьому» на нове - «вчити вчитися» [7, с. 28].

У цьому контексті варто зазначити, що на спільному засіданні Європейської Ради й представників урядів держав-членів у Люксембурзі у 2006 р. підкреслювалось, що посилення ефективності та справедливості в освіті є ключовими завданнями в умовах глобалізаційних викликів, демографічних змін, швидкого розвитку технологій та зростання навантаження на державні бюджети [8, с. 298/4].

Європейський досвід демонструє, що освітня сфера заради реалізації поставлених вище завдань потребує належного фінансування, що є складним завданням для сучасної України. В умовах ринкових відносин варто розуміти, що «дешева освіта» не може продукувати якісних спеціалістів.

Як відзначається у документі Свропейської Ради «Висновки Ради щодо контрольних рівнів середніх європейських досягнень в освіті та професійній підготовці (контрольні показники)» (Council Conclusions on Reference Levels of European Average Performance in Education and Training (Benchmarks, 2003), інвестиції в освіту є інвестиціями на перспективу з непрямими, а також прямими прибутками, і більшість урядів вважають, що вони здійснюють позитив- 
ний вплив щодо таких ключових викликів, як соціальна злагода, міжнародна конкуренція та сталий розвиток [9, с. 6].

Таким чином, філософія освіти ринково орієнтованого суспільства спрямована на інноваційні зміни у системі освіти, на оптимізацію мережі навчальних закладів, на багатоканальне фінансування освітньої сфери, на підняття якості навчально-виховного процесу та ін. Досліджуючи досвід західних країн, Україна, на нашу думку, має вибудувати власну освітню модель, яка відповідає сучасним реаліям та вітчизняним традиціям. Така модель відповідно із західним досвідом може базуватися на принципах децентралізації, інноваційності, соціально-економічних стимулів до науковопедагогічної діяльності, гнучкості, демократичності у побудові відносин між суб'єктами освітнього поля.

\section{ЛITEPAТУРА}

1. Філософія освіти: Навчальний посібник / заг. ред. В. Андрущенка, І. Передборської. Київ : Вид-во НПУ імені М. П. Драгоманова, 2009. 329 с.

2. Тульчинский Г. Л. Менеджмент в сфере культуры / Г. Л. Тульчинский, Е. Л. Щекова. СПб. : Лань, 2003. 528 с.

3. Ситниченко С. Г. Інноваційний характер маркетингової парадигми управління освітою. Грані. 2014. № 11. С. 49-53.

4. Кристопчук Т. Є. Особливості децентралізації управління освітою: досвід європейських країн. Психолого-педагогічні основи гуманізаиії навчально-виховного процесу в школі та ВНЗ. 2016. Вип. 2. С. 108-117.

5. Управління системою освіти територіальних громад: досвід країн Вишеградської четвірки для України: методичний посібник із збіркою кращих практик / А. Кавунець, А. Ланова, О. Гуменна, О. Черній, Р. Шарлея, Л. Грегуркова, Л. Одор, Л. Лакатош, Ш. Кьолеш, Е. Бураш. Вінниця : ТОВ «Твори», 2018. $120 \mathrm{c.}$

6. Функціонування опорних шкіл. За результатами опитування директорів опорних шкіл. МОН України, Інститут освітньої аналітики. 2017. $79 \mathrm{c}$.

7. Локшина О. І. Зміст шкільної освіти в країнах Європейського Союзу: теорія і практика (друга половина XX - початок XXI ст.) : монографія. Київ : Богданова А. М., 2009. 404 с.

8. European Union. Draft Conclusions of the Council and the Representatives of 357. The Governments of the Member States, Meeting within the 
Council, on the Efficiency and Equity in Education and Training (2006/C 298/03). Official Journal of the European Union. 2006. 8 December. P. 298/3.

9. European Union. Council Conclusions on Reference Levels of European Aver-353. Age Performance in Education and Training (Benchmarks). Outcome of Proceedings. 2003, 7 May. 8981/3. EDUC 83. Brussels : Council of the European Union, 2003. 7 p.

\section{REFERENCES}

Andrushchenko, V. \& Predborska, I. (Ed.). (2009). Philosophy of Education: Tutorial. Kyiv: National Pedagogical Drahomanov University. 329 p. [In Ukrainian].

Tulchinsky, H. \& Shchekova, E. (2003). Management in the field of culture. 528 p. [In Russian].

Sytnychenko, E. (2014). Innovative nature of the marketing paradigm of education management. Hrani [Faces]. Issue 11, pp. 49-53. [In Ukrainian].

Krystopchuk, T. (2016). Features of decentralization of education management: the experience of European countries. Psychological and pedagogical foundations of humanization of the educational process in school and university. Issue 2, pp. 108-117. [In Ukrainian].

Kavunets, A., Lanova, A., Humenna, O., Cherniy, O., Charley, R. and other (2018). Management of the system of education of territorial communities: experience of the Visegrad Four countries for Ukraine: a manual with a collection of best practices. Vinnytsia: LLC "Tvory". 120 p. [In Ukrainian].

Functioning of support schools. (2017). According to a survey of principals of support schools / Ministry of Education and Science of Ukraine. Institute of Educational Analytics. 79 p. [In Ukrainian].

Lokshina, O. (2009). The content of school education in the countries of the European Union: theory and practice (second half of the XX-beginning of the XXI century): monograph. 404 p. [In Ukrainian].

European Union. (2006). Draft Conclusions of the Council and the Representatives of 357. The Governments of the Member States, Meeting within the Council, on the Efficiency and Equity in Education and Training (2006/C 298/03). In: Official Journal of the European Union. 8 December. P. C 298/3. C 298/6. 
European Union (2003). Council Conclusions on Reference Levels of European Aver-353. Age Performance in Education and Training (Benchmarks). Outcome of Proceedings. 7 May. 8981/3. EDUC 83. Brussels: Council of the European Union, 2003. 7 p.

\title{
Mykhailo Kit
}

Post-Graduate Student, National Pedagogical Dragomanov University; Kyiv, Ukraine; e-mail: kit-mi@ukr.net; ORCID: https://orcid.org/0000-0002-39717063

\section{Philosophy of education of market-oriented society: Ukrainian experience}

\begin{abstract}
s
The article emphasizes that the school in the modern world focuses on the full preparation of youth for a successful life. This requires the application of a fundamentally new philosophy of education that would meet the needs of a market-oriented, competitive society. It is important to study Western models of organization of educational systems to use their experience in the successful transformation of the Ukrainian educational sector on the basis of decentralization. It is noted that the philosophy of education of a market-oriented society is aimed at innovative changes in the education system, optimization of the network of educational institutions, multi-channel financing of the educational sphere, raising the quality of the educational process and others. Examining the experience of Western countries, Ukraine, in our opinion, should build its own educational model that corresponds to modern realities and national traditions. Such a model can be based on the principles of decentralization, innovation, socio-economic incentives for scientific and pedagogical activities, flexibility, democracy in building relations between the subjects of the educational field. European experience shows that the educational sphere needs adequate funding to implement the tasks set above, which is a difficult for modern Ukraine. In market conditions, it should be understood that «cheap education» can not produce quality professionals. The Ukrainian education system is still in the process of transitioning from outdated authoritarian forms of education to new standards and methods. In general, the philosophy of education of a market-oriented society in its western version is aimed at constantly updating knowledge, improving the level of educational services, ensuring accessibility of citizens to educational institutions of different levels, creating conditions for
\end{abstract}


ISSN 2078-8142 Multiversum. Philosophical almanac. 2020. Issue 2(172). Vol. 2.

lifelong learning, maintaining the practical orientation of education and others.

Keywords: philosophy of education, educational system, market society, decentralization. 